\title{
Effect of glucocorticoids on mortality in patients with acute respiratory distress syndrome: A meta-analysis
}

\author{
QING ZHAO ${ }^{1}$, JIA-XIN SHI ${ }^{2}$, RONG HU ${ }^{2}$, QIN LI ${ }^{2}$, CHEN-YING ZHANG ${ }^{2}$ and JIA-SHU LI ${ }^{2}$ \\ ${ }^{1}$ Outpatient Department; ${ }^{2}$ Department of Pulmonary and Critical Care Medicine, \\ The First People's Hospital of Lianyungang, Lianyungang, Jiangsu 222002, P.R. China
}

Received March 12, 2019; Accepted August 30, 2019

DOI: $10.3892 /$ etm.2019.8156

\begin{abstract}
To date, the efficacy of glucocorticoid therapy to reduce mortality in patients with acute respiratory distress syndrome (ARDS) has remained controversial among the studies available. The present meta-analysis study aimed to further clarify the impact of glucocorticoid therapy on mortality in patients with ARDS by performing a pooled analysis of the previous data. The PubMed, Chinese Knowledge Infrastructure, Wanfang and Cochrane trials databases were searched for relevant studies published between 1966 and 2016. Randomized controlled trials (RCTs) that included the use of glucocorticoids in patients with ARDS and had reported on mortality were included. Odds ratios (OR) and 95\% confidence intervals (CI) for mortality were calculated. A total of 10 RCTs were included in the meta-analysis. Of these, 4 studies used high-dose glucocorticoid therapy, while 6 used low-dose glucocorticoid therapy. In the pooled analysis, glucocorticoids were indicated to significantly reduce ARDS-associated mortality $(\mathrm{OR}=0.64,95 \% \mathrm{CI}: 0.48-0.85, \mathrm{P}=0.002)$. Further subgroup analysis indicated the following: i) Long-term low-dose glucocorticoid therapy reduced ARDS-associated mortality compared with that in the control group $(\mathrm{OR}=0.60$, 95\% CI: 0.44-0.82, $\mathrm{P}=0.001$ ), whereas high-dose short-term glucocorticoid therapy did not reduce mortality $(\mathrm{OR}=0.82$, 95\% CI: 0.43-1.57, $\mathrm{P}=0.55)$. ii) Early initiation of glucocorticoid therapy was associated with reduced mortality compared with that in the control group $(\mathrm{OR}=0.60,95 \% \mathrm{CI}: 0.44-0.83$, $\mathrm{P}=0.002)$; however, late initiation did not reduce mortality $(\mathrm{OR}=0.36$, 95\% CI: 0.03-3.76, $\mathrm{P}=0.39)$. iii) Therapeutic rather than preventive use of glucocorticoids reduced mortality $(\mathrm{OR}=0.65$, 95\% CI: $0.49-0.86, \mathrm{P}=0.003)$. Overall, the present
\end{abstract}

Correspondence to: Professor Jia-Xin Shi or Professor Jia-Shu Li, Department of Pulmonary and Critical Care Medicine, The First People's Hospital of Lianyungang, 182 Northern Tongguan Road, Lianyungang, Jiangsu 222002, P.R. China

E-mail: shijiaxin919@126.com

E-mail: ljssm1118@sina.com

Key words: acute respiratory distress syndrome, acute lung injury, glucocorticoids, mortality meta-analysis suggests that early initiation of long-term low-dose glucocorticoid therapy reduces mortality of patients with ARDS.

\section{Introduction}

Acute respiratory distress syndrome (ARDS) refers to acute inflammatory injury to the lung. The condition is characterized by increased vascular permeability, extravasation of plasma, pulmonary edema and acute hypoxemic respiratory failure (1). ARDS is associated with a high mortality rate. Several treatment strategies have been applied for patients affected; however, only few of these, with the exception of lung-protective mechanical ventilation, have had an impact on ARDS outcomes $(2,3)$. Since inflammation is a key pathogenetic mechanism of ARDS (1), it is reasonable to explore therapies that modulate acute lung inflammation.

Glucocorticoids are the most commonly used anti-inflammatory and immunomodulatory drugs. Studies that investigated the role of glucocorticoids in ARDS have yielded inconsistent results. Several studies indicated that glucocorticoids did not reduce the risk of ARDS-associated mortality (4-6). However, in one study, glucocorticoids were reported to reduce the intensive care unit (ICU) mortality in patients with ARDS (7). The present meta-analysis was performed to assess the effect of glucocorticoid therapy on mortality in patients with ARDS.

\section{Materials and methods}

Selection of studies. The PubMed (reference period: January 1, 1966 to December 31, 2016), Chinese Knowledge Infrastructure and Wanfang databases (reference period: January 1,1982 to December 31, 2016), and the Cochrane trials database (reference period: January 1, 1966 to December 31, 2016) were searched for all relevant publications pertaining to acute lung injury and ARDS.

The following search terms were used: 'acute lung injury', 'acute respiratory distress syndrome' AND 'glucocorticoids', 'corticosteroid', 'steroid', 'methylprednisolone', 'dexamethasone', 'hydrocortisone', 'prednisolone' AND 'randomized', 'random', 'randomly' AND 'patient'. If a study was included in a review and was indexed in the PubMed database, associated studies were further explored using the 


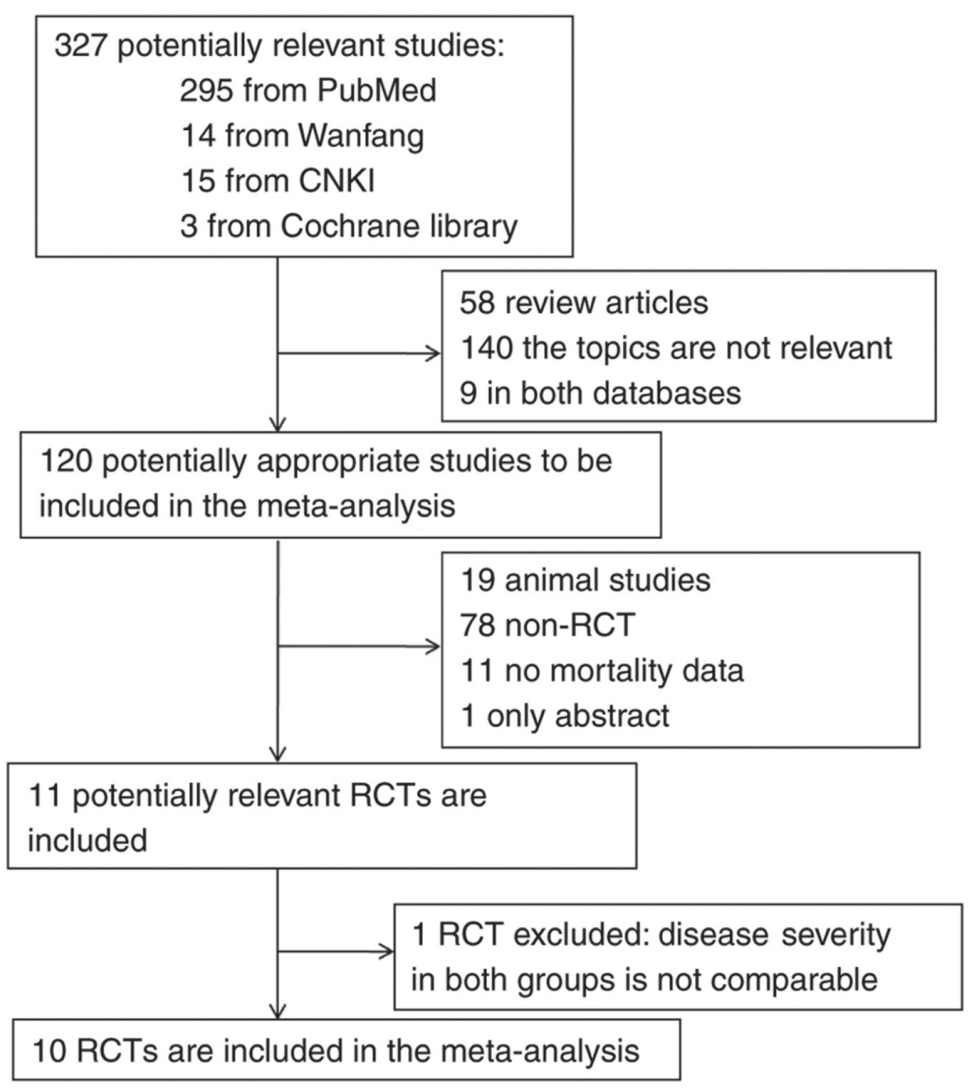

Figure 1. Schematic illustration of literature search and study-selection criteria. RCT, randomized controlled trial; CNKI, Chinese Knowledge Infrastructure.

'Related Articles' option. The reference lists of relevant papers were manually screened to identify additional studies.

Randomized controlled trials (RCTs) that fulfilled the following criteria were included: i) Patients with ARDS; ii) patients aged $\geq 18$ years; and iii) use of glucocorticoids. The trials were excluded if they i) were non-RCTs; ii) were published as an abstract only; or iii) did not report the mortality data.

Quality assessment. Three reviewers independently assessed the methodological quality using a 10-point scoring system based on a previous meta-analysis (8). This 10-piont scoring system includes 'Randomization', 'Allocation concealment', 'Blinding', 'Inclusion and exclusion criteria defined', 'Similar baseline at study entry', 'Treatment protocol clearly described', 'Cointervention that may affect outcome', 'Outcome definition', 'Extent of follow-up clearly described' and 'Intention-to-treat analysis'. In contrast, Cochrane system includes 'Sequence generation', 'Allocation concealment', 'Blinding of participants, personnel and outcome assessors', 'Incomplete outcome data', 'Selective outcome reporting' and 'Other sources of bias' (Cochrane Handbook for Systematic Reviews of Interventions). Since the 10-point scoring system includes more parameters compared with Cochrane, the former scoring system was chosen.

Data extraction and clinical outcomes. The identification of trials and data extraction were independently performed by two reviewers (QL and CYZ), and any disagreements were resolved via consultation with a third reviewer $(\mathrm{RH})$. The outcome measure was mortality.
Statistical analysis. Meta-analysis was performed using the Mantel-Haentzel method to calculate the odds ratios (OR) for mortality along with $95 \%$ confidence interval (CI) (8). Heterogeneity among the studies was assessed using the Cochran's Q statistic. In case of lack of significant heterogeneity $(\mathrm{P}>0.05)$, the fixed-effects model was used for the meta-analysis, while a random-effects model was used in case of significant heterogeneity $(\mathrm{P} \leq 0.05)$. The degree of heterogeneity was tested with $\mathrm{I}^{2}$ statistics using the Review Manager software; values $<25 \%$ were considered indicative of low heterogeneity, while values of $25-50 \%$ and $>50 \%$ were considered indicative of moderate and high heterogeneity, respectively (9). The meta-analysis was performed using Review Manager 5.0.24 (Cochrane Library Software).

\section{Results}

Selection and characteristics of trials. A flow chart depicting the study selection is provided in Fig. 1. A total of 327 articles (298 in English language and 29 in Chinese), were retrieved in the database search. Any studies published in languages other than English and Chinese were excluded. Of these, 316 studies that were not relevant were excluded. One study was excluded due to the serum creatinine levels in the methylprednisolone group were significantly higher compared with those in the control group (10), implying that disease severity in the two groups was not comparable. Except for serum creatinine levels, other baseline parameters, including age, sex, etiology and blood pressure in both groups were 
Table I. Characteristics of the randomized controlled trials included in the meta-analysis.

\begin{tabular}{|c|c|c|c|c|c|c|}
\hline $\begin{array}{l}\text { First } \\
\text { author (year) }\end{array}$ & Group & $\begin{array}{c}\text { Age } \\
(\text { years })^{\mathrm{a}}\end{array}$ & $\mathrm{PaO}_{2} / \mathrm{FiO}_{2}$ & ARDS definition & Etiologic factors & (Refs.) \\
\hline Weigelt (1985) & $\begin{array}{l}\mathrm{GC}(\mathrm{n}=25) \\
\text { Control }(\mathrm{n}=14)\end{array}$ & $\begin{array}{l}19-75 \\
19-72\end{array}$ & $\begin{array}{l}165-350 \\
95-345\end{array}$ & $\begin{array}{l}\mathrm{PaO}_{2}<100 \mathrm{mmHg} \\
\text { on } 40 \% \text { oxygen or } \\
\mathrm{PaO}_{2}<350 \mathrm{mmHg} \\
\text { on } 100 \% \text { oxygen. }\end{array}$ & $\begin{array}{l}\text { Sepsis, shock, massive } \\
\text { transfusion, contusion, } \\
\text { alveolar hypoventilation, } \\
\text { aspiration. }\end{array}$ & (4) \\
\hline Bernard (1987) & $\begin{array}{l}\mathrm{GC}(\mathrm{n}=50) \\
\text { Control }(\mathrm{n}=49)\end{array}$ & $\begin{array}{l}55 \pm 2 \\
56 \pm 2\end{array}$ & $\begin{array}{l}\text { NA } \\
\text { NA }\end{array}$ & $\begin{array}{l}\text { (1) } \mathrm{PaO}_{2} \leq 70 \mathrm{mmHg} \\
\text { on } 40 \% \text { oxygen; } \\
\text { (2) Bilateral diffuse } \\
\text { infiltrates on chest } \\
\text { radiography and } \\
\text { (3) PAWP } \leq 18 \mathrm{mmHg} \text {. }\end{array}$ & $\begin{array}{l}\text { Sepsis, aspiration, infectious } \\
\text { pneumonia, pancreatitis, } \\
\text { shock, fat emboli, and other } \\
\text { causes or multiple causes. }\end{array}$ & $(11)$ \\
\hline Luce (1988) & $\begin{array}{l}\mathrm{GC}(\mathrm{n}=38) \\
\text { Control }(\mathrm{n}=37)\end{array}$ & $\begin{array}{l}50 \pm 2.5 \\
53 \pm 2.5\end{array}$ & $\begin{array}{l}\text { NA } \\
\text { NA }\end{array}$ & $\begin{array}{l}\text { (1) The new onset of } \\
\text { diffuse infiltrates involving } \\
\text { all } 4 \text { quadrants of the chest } \\
\text { roentgenogram; } \\
\text { (2) } \mathrm{PaO}_{2} / \mathrm{PAO}_{2}<0.30 \text { and } \\
\text { (3) } \mathrm{PAWP} \leq 18 \mathrm{mmHg} \text {. }\end{array}$ & $\begin{array}{l}\text { Pneumonia, peritonitis } \\
\text { and others. }\end{array}$ & $(5)$ \\
\hline Meduri (1998) & $\begin{array}{l}\mathrm{GC}(\mathrm{n}=16) \\
\text { Control }(\mathrm{n}=8)\end{array}$ & $\begin{array}{l}47 \pm 3.9 \\
51 \pm 6.6\end{array}$ & $\begin{array}{l}110 \pm 11 \\
123 \pm 11\end{array}$ & AECC criteria & NA & $(12)$ \\
\hline Confalonieri (2005) & $\begin{array}{l}\mathrm{GC}(\mathrm{n}=23) \\
\text { Control }(\mathrm{n}=23)\end{array}$ & $\begin{array}{l}60.4 \pm 17.3 \\
66.6 \pm 14.7\end{array}$ & $\begin{array}{l}141 \pm 49 \\
178 \pm 58\end{array}$ & AECC criteria & CAP & (13) \\
\hline Steinberg (2006) & $\begin{array}{l}\text { GC }(n=89) \\
\text { Control }(n=91)\end{array}$ & $\begin{array}{l}49.0 \pm 19.0 \\
49.2 \pm 16.5\end{array}$ & $\begin{array}{l}126 \pm 42 \\
126 \pm 40\end{array}$ & AECC criteria & $\begin{array}{l}\text { Trauma, sepsis, multiple } \\
\text { transfusions, aspiration, } \\
\text { pneumonia and other. }\end{array}$ & (6) \\
\hline Annane (2006) & $\begin{array}{l}\mathrm{GC}(\mathrm{n}=85) \\
\text { Control }(\mathrm{n}=92)\end{array}$ & $\begin{array}{l}61 \pm 16 \\
59 \pm 18\end{array}$ & $\begin{array}{l}\text { NA } \\
\text { NA }\end{array}$ & AECC criteria & $\begin{array}{l}\text { Lung and other infections } \\
\text { with septic shock. }\end{array}$ & $(14)$ \\
\hline Meduri (2007) & $\begin{array}{l}\text { GC }(n=63) \\
\text { Control }(n=28)\end{array}$ & $\begin{array}{l}50.1 \pm 15.3 \\
53.2 \pm 15.3\end{array}$ & $\begin{array}{l}118.4 \pm 51.2 \\
125.9 \pm 38.6\end{array}$ & AECC criteria & $\begin{array}{l}\text { Pneumonia, aspiration of } \\
\text { gastric content, sepsis and } \\
\text { other. }\end{array}$ & (7) \\
\hline Seam (2012) & $\begin{array}{l}\mathrm{GC}(\mathrm{n}=55) \\
\text { Control }(\mathrm{n}=24)\end{array}$ & $\begin{array}{l}49.7 \pm 2.1 \\
53.9 \pm 3.4\end{array}$ & $\begin{array}{l}119.5 \pm 6.9 \\
126.2 \pm 8.2\end{array}$ & AECC criteria & $\begin{array}{l}\text { CAP, HAP, intra-abdominal } \\
\text { and urinary tract infection, } \\
\text { endocarditis, necrotizing } \\
\text { fasciitis, bacteremia of } \\
\text { unknown source, ehrlichiosis, } \\
\text { aspiration, postoperation, } \\
\text { pancreatitis and other. }\end{array}$ & $(15)$ \\
\hline Tongyoo (2016) & $\begin{array}{l}\mathrm{GC}(\mathrm{n}=98) \\
\text { Control }(\mathrm{n}=99)\end{array}$ & $\begin{array}{l}64.5 \pm 17.3 \\
64.3 \pm 16.0\end{array}$ & $\begin{array}{l}175.4 \pm 6.9 \\
172.4 \pm 6.7\end{array}$ & AECC criteria & Severe sepsis or septicshock. & $(16)$ \\
\hline
\end{tabular}

GC, glucocorticoid; $\mathrm{PaO}_{2}$, partial pressure of oxygen in artery; $\mathrm{FiO}_{2}$, fraction of inspired oxygen; PAWP, pulmonary artery wedge pressure; AECC, American-European Consensus Conference; NA, not available; CAP, community-acquired pneumonia; HAP, hospital-acquired

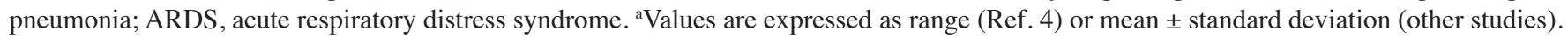

comparable (10). A total of 10 RCTs fulfilled the inclusion criteria and were selected for the final analysis (4-7,11-16). The characteristics of the studies included are summarized in Table I. The major categories of ARDS risk factors included pneumonia, sepsis, trauma, shock and aspiration. The definition of ARDS in the studies included was largely consistent with the Berlin definition (17).
The treatment regimens and mortality data are provided in Table II. The treatment regimens varied considerably between studies (Table II). In 8 studies, glucocorticoid treatment was initiated in the early phase of ARDS (within 1 week of diagnosis) $(4,5,7,11,13,14-16)$; in 2 studies, glucocorticoid therapy was initiated in the later phase of ARDS ( $>1$ week after diagnosis) $(6,12)$. The dosage of glucocorticoids ranged from 40 to 
Table II. Treatment regimens and mortality data of the trials included in the meta-analysis.

\begin{tabular}{|c|c|c|c|c|c|c|c|}
\hline $\begin{array}{l}\text { First } \\
\text { author (year) }\end{array}$ & $\begin{array}{l}\text { Treatment } \\
\text { timing }\end{array}$ & Drug & $\begin{array}{l}\text { Dosing and course } \\
\text { of treatment }\end{array}$ & $\begin{array}{c}\text { Intention (prevention } \\
\text { or treatment) }\end{array}$ & $\begin{array}{l}\text { Mortality } \\
\text { end-point }\end{array}$ & $\begin{array}{l}\text { Mortality status } \\
\text { (dead/alive) }\end{array}$ & (Refs.) \\
\hline Weigelt (1985) & Early & MTPS & $120 \mathrm{mg} / \mathrm{kg} / \mathrm{d}$ for $2 \mathrm{~d}$ & Treatment & Hospital & $\begin{array}{l}\text { GC: } 11 / 14 \\
\text { Control: } 6 / 8\end{array}$ & (4) \\
\hline Bernard (1987) & Early & MTPS & $120 \mathrm{mg} / \mathrm{kg} / \mathrm{d}$ for $1 \mathrm{~d}$ & Treatment & $45 \mathrm{~d}$ & $\begin{array}{l}\text { GC: } 30 / 20 \\
\text { Control: } 31 / 18\end{array}$ & (11) \\
\hline Luce (1988) & Early & MTPS & $8 \mathrm{mg} / \mathrm{kg} / \mathrm{d}$ for $1 \mathrm{~d}$ & Prevention & Hospital & $\begin{array}{l}\text { GC: } 9 / 4 \\
\text { Control: } 12 / 2\end{array}$ & (5) \\
\hline Meduri (1998) & Later & MTPS & $\begin{array}{l}2 \mathrm{mg} / \mathrm{kg} / \mathrm{d} \text { for } 4 \mathrm{~d} \\
\text { and tapering; } 32 \mathrm{~d}\end{array}$ & Treatment & Hospital & $\begin{array}{l}\text { GC: } 2 / 14 \\
\text { Control: } 5 / 3\end{array}$ & (12) \\
\hline Confalonieri (2005) & Early & Hyd & $\begin{array}{l}\text { Single } 200 \mathrm{mg} \\
\text { followed by } \\
240 \mathrm{mg} / \mathrm{d} ; 7 \mathrm{~d}\end{array}$ & Treatment & $\begin{array}{l}\text { Hospital } \\
\text { and } 60 \mathrm{~d}\end{array}$ & $\begin{array}{l}\text { GC: } 0 / 23 \\
\text { Control: } 7 / 16\end{array}$ & (13) \\
\hline Steinberg (2006) & Later & MTPS & $\begin{array}{l}\text { Single } 2 \mathrm{mg} / \mathrm{kg} \\
\text { followed by } \\
2 \mathrm{mg} / \mathrm{kg} / \mathrm{d} \text { for } 14 \mathrm{~d} \\
\text { and tapering; } 25 \mathrm{~d}\end{array}$ & Treatment & $60 \mathrm{~d}$ & $\begin{array}{l}\text { GC: } 28 / 61 \\
\text { Control: } 29 / 62\end{array}$ & (6) \\
\hline Annane (2006) & Early & Hyd & $200 \mathrm{mg} / \mathrm{d} ; 7 \mathrm{~d}$ & Treatment & $28 \mathrm{~d}$ & $\begin{array}{l}\text { GC: } 54 / 31 \\
\text { Control: } 67 / 25\end{array}$ & (14) \\
\hline Meduri (2007) & Early & MTPS & $\begin{array}{l}\text { Single } 1 \mathrm{mg} / \mathrm{kg} \\
\text { followed by } \\
1 \mathrm{mg} / \mathrm{kg} / \mathrm{d} \text { for } 14 \mathrm{~d} \\
\text { and tapering; } 28 \mathrm{~d}\end{array}$ & Treatment & Hospital & $\begin{array}{l}\text { GC: } 15 / 48 \\
\text { Control: } 12 / 16\end{array}$ & (7) \\
\hline Seam (2012) & Early & MTPS & $\begin{array}{l}1 \mathrm{mg} / \mathrm{kg} / \mathrm{d} \text { for } 14 \mathrm{~d} \\
\text { and tapering; } 28 \mathrm{~d}\end{array}$ & Treatment & ICU stay & $\begin{array}{l}\text { GC: } 11 / 44 \\
\text { Control: } 10 / 14\end{array}$ & (15) \\
\hline Tongyoo (2016) & Early & Hyd & $50 \mathrm{mg} 4 / \mathrm{d} ; 7 \mathrm{~d}$ & Treatment & $60 \mathrm{~d}$ & $\begin{array}{l}\text { GC: } 34 / 64 \\
\text { Control: } 40 / 59\end{array}$ & (16) \\
\hline
\end{tabular}

MTPS, methylprednisolone; Hyd, hydrocortisone; GC, glucocorticoid; ICU, intensive care unit; d, days.

60 or 1 to $2 \mathrm{mg} / \mathrm{kg} /$ day of methylprednisolone or equivalent. Glucocorticoid doses were tapered in 4 studies $(6,7,12,15)$. The treatment duration was also different among studies (range, 1-32 d). Due to limitations in the understanding of the mechanisms and characteristics of ARDS, in that ARDS was at first thought to be a short-term acute inflammation in the lung in the past, glucocorticoids were used only for 1 or 2 days in 3 early studies $(4,5,11)$. Glucocorticoids were used to treat but not prevent ARDS in most studies except for one study (5).

A summary of the methodological quality and the score for each of the trials included is provided in Table III. The studies included in the meta-analysis scored 7 points on average in the 10-point scoring system, which was indicative of high quality.

Mortality outcomes. The pooled analysis revealed that glucocorticoid therapy for ARDS was associated with reduced mortality compared with the controls. The OR for mortality after glucocorticoid therapy was 0.64 (95\% CI: 0.48-0.85, $\mathrm{P}=0.002$; fixed-effects model) compared with the control group (Fig. 2A).

Next, subgroup analysis according to the dose, duration of glucocorticoid therapy and the timing of intervention were performed. The results indicated that long-term ( $\geq 7 \mathrm{~d})$ low-dose glucocorticoid therapy (40-60 or 1-2 mg/kg/d methylprednisolone or equivalent) $(6,7,12,13,14-16)$ reduced ARDS-associated mortality compared with that in the control group $(\mathrm{OR}=0.60$, 95\% CI: 0.44-0.82, P=0.001; fixed-effects model; Fig. 2B). A total of 3 studies evaluated short-term ( $<7$ days) high-dose glucocorticoid therapy $(4,5,11)$ and the result showed that short-term ( $<7$ days) high-dose glucocorticoid therapy did not affect ARDS-associated mortality (OR=0.82, 95\% CI: 0.43-1.57, $\mathrm{P}=0.55$; fixed-effects model; Fig. 2C).

Initiation of glucocorticoid therapy in the early phase of ARDS (within 1 week of diagnosis) significantly reduced ARDS-associated mortality compared with that in the control group $(\mathrm{OR}=0.60,95 \% \mathrm{CI}$ : 0.44-0.83, $\mathrm{P}=0.002$; fixed-effects model; Fig. 2D); however, initiation of glucocorticoid therapy in the later phase of ARDS ( $>1$ week after diagnosis) had no effect on mortality $(\mathrm{OR}=0.36,95 \% \mathrm{CI}$ : 0.03-3.76, $\mathrm{P}=0.39$; random-effects model; Fig. 2E).

Preventive use of glucocorticoids in critically ill patients did not reduce ARDS-associated mortality compared with that in the control group (5); however, therapeutic use of 


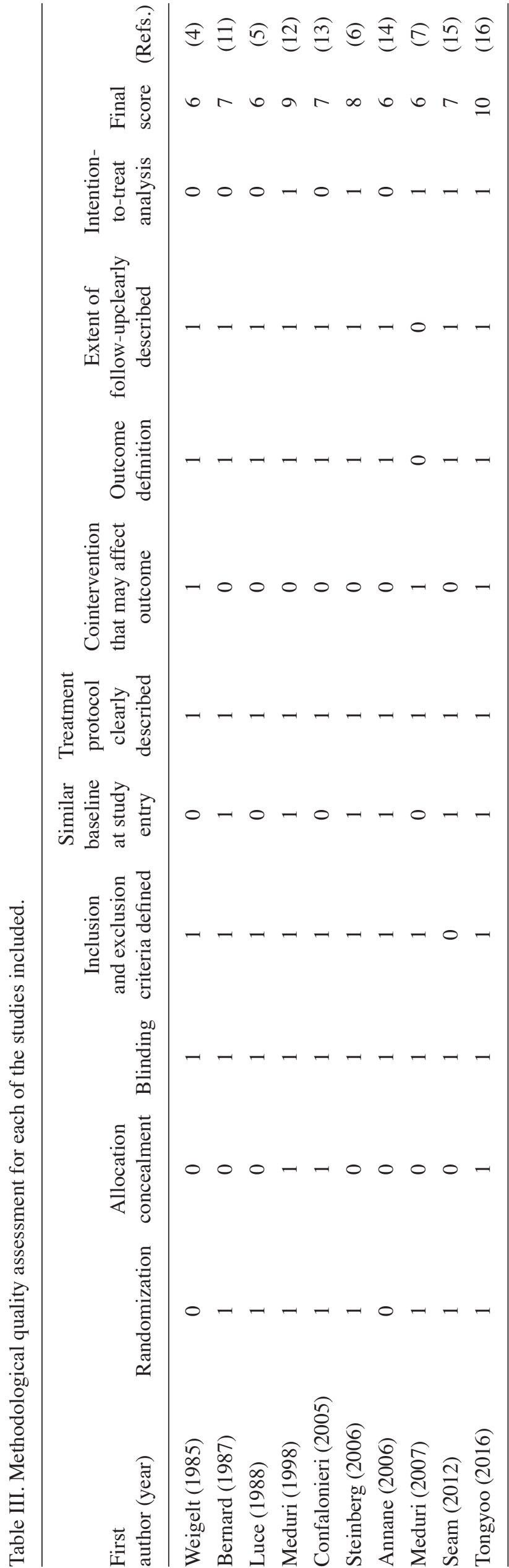

glucocorticoids significantly reduced ARDS-associated mortality (OR=0.65, 95\% CI: 0.49-0.86, $\mathrm{P}=0.003$; fixed-effects model; Fig. 2F).

The effect of combined early initiation, long-term low dose glucocorticoids on ARDS-associated mortality were next compared to all other combinations. The pooled analysis results showed that the combination of early initiation, long-term low dose glucocorticoids $(7,13,14-16)$ significantly reduced ARDS-associated mortality (OR=0.54, 95\% CI: 0.37-0.79, $\mathrm{P}=0.001$; fixed-effects model; Fig. $2 \mathrm{G}$ ), whilst all other combinations $(4-6,11,12)$ exerts no effects on ARDS-associated mortality (OR=0.80, 95\% CI: 0.52-1.23, $\mathrm{P}=0.30$; fixed-effects model; Fig. 2H).

\section{Discussion}

ARDS is a common type of organ failure in critically ill patients and is associated with high morbidity and mortality (18). Development of effective therapies for ARDS is an active area of research. Although lung-protective mechanical ventilation improves outcomes for patients with ARDS (2), there are currently pharmacological therapies for ARDS with proven effectiveness. Considering the pivotal role of acute inflammation in the pathogenesis of ARDS, several studies have investigated the use of glucocorticoids in these patients $(4,7,13)$; however, the results were largely inconsistent. The present meta-analysis suggested that glucocorticoids reduce ARDS-associated mortality. In particular, long-term low-dose glucocorticoid therapy, when initiated at an early stage, was associated with reduced mortality. These results indicate that glucocorticoids have a promising role in ARDS.

There was much variability between the studies included with regard to the dosage and duration of glucocorticoid therapy. In early times, short-term ( $<7$ days) high-dose glucocorticoids (up to $120 \mathrm{mg} / \mathrm{kg} / \mathrm{d}$ of methylprednisolone or equivalent) were typically used to treat or prevent ARDS $(4,5,11)$. For the early studies did not show the benefit from short-term high-dose glucocorticoids treatment, and then most studies used low-dose glucocorticoids (40-60 or 1-2 mg/kg/day omethylprednisolone or equivalent) with tapering over a relatively long period for therapeutic rather than prophylactic purposes $(6,7,12,13,14-16)$. Based on the results of the present pooled analysis, long-term treatment with low-dose glucocorticoid provided a survival benefit, while short-term treatment at a high dose did not, which is similar to the results obtained by Meduri et al (19). The reason may be that in ARDS, inflammation tends to persist for a long time (20); therefore, the long-term use of glucocorticoids may have a persistent effect on ARDS. On the contrary, short-term use of high-dose glucocorticoids had no significant beneficial effect to reduce mortality and was associated with a high incidence of side effects $(4,5,11)$. Relevant Guidelines of the Society of Critical Care Medicine and European Society of Intensive Care Medicine 2017 conditionally recommend the use of methylprednisolone in early ARDS (up to day 7 of onset) at a dose of $1 \mathrm{mg} / \mathrm{kg} / \mathrm{d}$; for late persistent ARDS (after day 6 of onset), the guidelines recommend a dose of $2 \mathrm{mg} / \mathrm{kg} / \mathrm{d}$ followed by gradual tapering (21).

The timing of initiation of glucocorticoid therapy for ARDS is another issue of interest. The present results suggest 


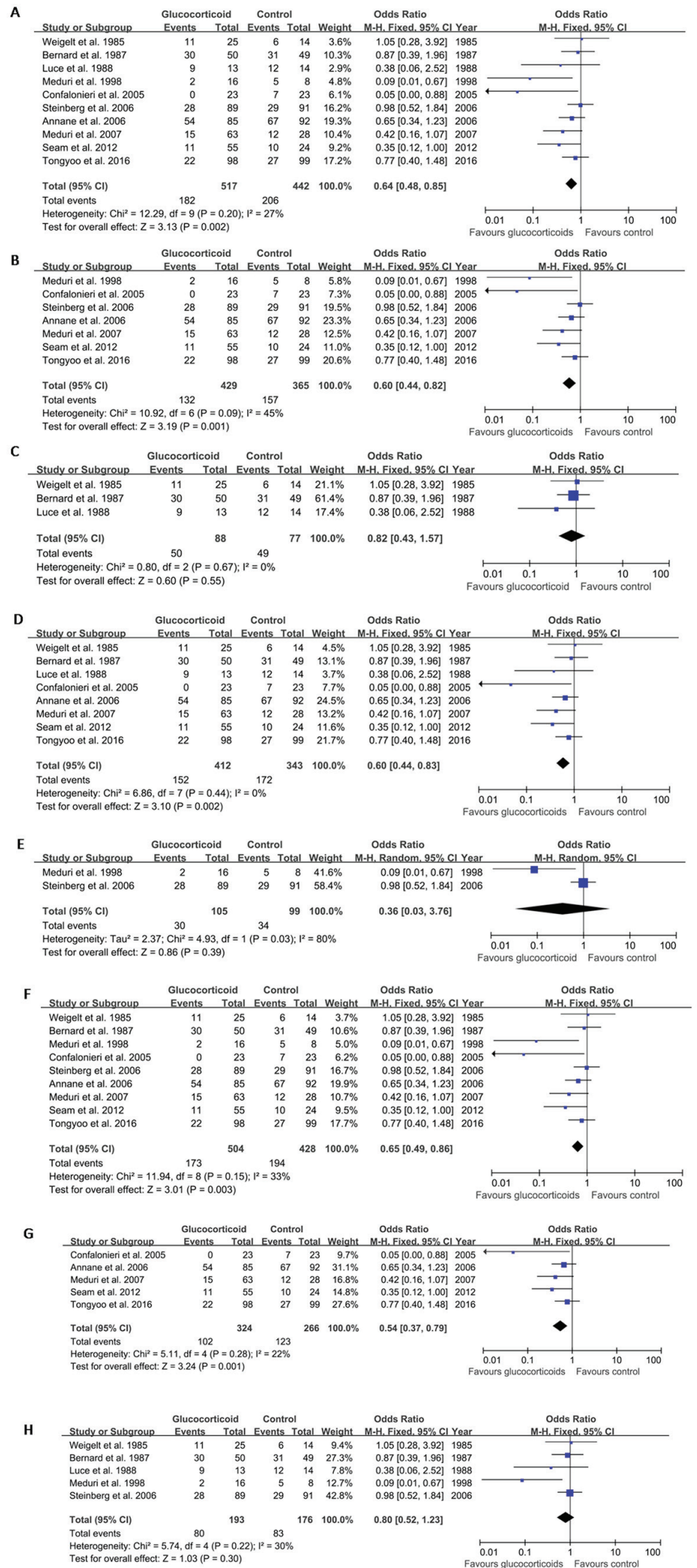

Figure 2. Combined analysis for mortality in ARDS patients comparing glucocorticoid-treated patients with the control. (A) Pooled analysis for the studies included indicated that glucocorticoids reduce ARDS-associated mortality compared with that in the control group. (B) Subgroup analysis indicated that long-term low-dose glucocorticoid therapy reduced ARDS-associated mortality; however, (C) short-term high-dose glucocorticoid therapy had no effect on ARDS-associated mortality compared with that in the control group. (D) Initiation of glucocorticoid therapy within 1 week of ARDS markedly reduced ARDS-associated mortality. (E) Initiation of glucocorticoid therapy in the later phase of ARDS did not affect mortality. (F) Therapeutic rather than preventive use of glucocorticoids reduced ARDS-associated mortality. (G) The combination of early initiation, long-term low dose glucocorticoids significantly reduced ARDS-associated mortality. (H) All other combinations had no effect on ARDS-associated mortality. ARDS, acute respiratory distress syndrome; M-H, Mantel-Haentzel; df, degrees of freedom. 
that glucocorticoid treatment initiation within 1 week of ARDS onset provided a significant survival benefit, while treatment initiation at $>1$ week after ARDS diagnosis did not. This indicates that the use of glucocorticoids after the stage of irreversible lung injury may not offer much of a benefit.

Certain studies have explored the preventive application of glucocorticoids in critically ill patients; the results suggested that preventive use of glucocorticoids did not improve ARDS-associated mortality $(5,10,13)$, while therapeutic use of glucocorticoids, based on the pooled analysis results, reduced ARDS-associated mortality. It is obvious that an adequate inflammatory response in critically ill patients, particularly in infection patients, helps to eliminate invading pathogens; therefore, use of glucocorticoids in this phase may lead to adverse effects (22). However, when acute lung inflammation has progressed to ARDS, the use of glucocorticoids appears to provide a benefit by reducing excessive inflammation and the associated tissue injury.

The present meta-analysis has various limitations that should be considered. First, the studies included in the meta-analysis spanned $>20$ years. With advances in intensive care medicine, various novel techniques and therapeutic strategies have been developed, including lung-protective ventilation strategy and extracorporeal membrane oxygenation; these are likely to have had an impact on the mortality rate of patients with ARDS. Furthermore, although the studies included reported on in-hospital mortality data, the mortality end-points were not identical among the different studies since they either ICU or hospital mortality were also assessed; this may have introduced an element of bias. In addition, there are several etiological factors of ARDS, including infection, trauma, major operations and sepsis, and ARDS induced by different etiologic factors may be classified into different subphenotypes (23), which may influence the therapeutic response. However, based on the present results, it is impossible to identify any sub-groups of patients that are likely to benefit from glucocorticoid therapy. Finally, the effect of glucocorticoids on the long-term prognosis of patients with ARDS ( $>6$ months) is uncertain due to the relatively short duration of follow-up in most studies.

Overall, the present study suggested that early initiation of low-dose glucocorticoids with long-term administration reduces ARDS-associated mortality. Further well-designed prospective trials are required to provide recommendations for glucocorticoid use in ARDS subpopulations.

\section{Acknowledgements}

The authors would like to thank Professor Yi Shi from the Department of Pulmonary and Critical Care Medicine, Clinical School of Nanjing University (Nanjing, China) for the valuable discussion regarding the statistical analysis.

\section{Funding}

The present study was supported by the Six Talent Peaks Project of Jiangsu Province (grant no. 2019-SWYY-324), Jiangsu Province Key Medical Talents Program (grant no. QNRC2016504), Jiangsu Provincial Health and Family Planning Commission Science Foundation (grant no. H201558) and the Lianyungang Science and Technology Bureau Foundation (grant no. SH1401).

\section{Availability of data and materials}

The datasets used and/or analyzed during the current study are available from the corresponding author on reasonable request.

\section{Authors' contributions}

QZ, JXS and JSL conceived and designed the present study. RH, QL and CYZ performed data extraction. JXS and JSL ensured the quality of the data. QZ and QL analyzed the data. QZ, JXS and RH drafted the manuscript. All authors read and approved the final manuscript.

\section{Ethics approval and consent to participate}

Not applicable.

\section{Patient consent for publication}

Not applicable.

\section{Competing interests}

The authors declare that they have no competing interests.

\section{References}

1. Leaver SK and Evans TW: Acute respiratory distress syndrome. BMJ 335: 389-394, 2007.

2. Acute Respiratory Distress Syndrome Network, Brower RG, Matthay MA, Morris A, Schoenfeld D, Thompson BT and Wheeler A: Ventilation with lower tidal volumes as compared with traditional tidal volumes for acute lung injury and the acute respiratory distress syndrome. N Engl J Med 342: 1301-1308, 2000.

3. Boyle AJ, Mac Sweeney R and McAuley DF: Pharmacological treatments in ARDS; a state-of-the-art update. BMC Med 11: $166,2013$.

4. Weigelt JA, Norcross JF, Borman KR and Snyder WH III: Early steroid therapy for respiratory failure. Arch Surg 120: 536-540, 1985.

5. Luce JM, Montgomery AB, Marks JD, Turner J, Metz CA and Murray JF: Ineffectiveness of high-dose methylprednisolone in preventing parenchymal lung injury and improving mortality in patients with septic shock. Am Rev Respir Dis 138: 62-68, 1988.

6. Steinberg KP, Hudson LD, Goodman RB, Hough CL, Lanken PN Hyzy R, Thompson BT and Ancukiewicz M; National Heart, Lung, and Blood Institute Acute Respiratory Distress Syndrome (ARDS) Clinical Trials Network: Efficacy and safety of corticosteroids for persistent acute respiratory distress syndrome. The New England journal of medicine 354: 1671-1684, 2006.

7. Meduri GU, Golden E, Freire AX, Taylor E, Zaman M, Carson SJ Gibson $\mathrm{M}$ and Umberger R: Methylprednisolone infusion in early severe ARDS: Results of a randomized controlled trial. Chest 131: 954-963, 2007.

8. Peter JV, John P, Graham PL, Moran JL, George IA and Bersten A: Corticosteroids in the prevention and treatment of acute respiratory distress syndrome (ARDS) in adults: meta-analysis. BMJ 336: 1006-1009, 2008.

9. Higgins JP, Thompson SG, Deeks JJ and Altman DG: Measuring inconsistency in meta-analyses. BMJ 327: 557-560, 2003.

10. Bone RC, Fisher CJ Jr, Clemmer TP, Slotman GJ and Metz CA: Early methylprednisolone treatment for septic syndrome and the adult respiratory distress syndrome. Chest 92: 1032-1036, 1987.

11. Bernard GR, Luce JM, Sprung CL, Rinaldo JE, Tate RM, Sibbald WJ, Kariman K, Higgins S, Bradley R, Metz CA, et al: High-dose corticosteroids in patients with the adult respiratory distress syndrome. N Engl J Med 317: 1565-1570, 1987. 
12. Meduri GU, Headley AS, Golden E, Carson SJ, Umberger RA, Kelso T and Tolley EA: Effect of prolonged methylprednisolone therapy in unresolving acute respiratory distress syndrome: A randomized controlled trial. JAMA 280: 159-165, 1998.

13. Confalonieri M, Urbino R, Potena A, Piattella M, Parigi P, Puccio G, Della Porta R, Giorgio C, Blasi F, Umberger R and Meduri GU: Hydrocortisone infusion for severe communityacquired pneumonia: A preliminary randomized study. Am J Respir Crit Care Med 171: 242-248, 2005.

14. Annane D, Sébille V, Bellissant E and Ger-Inf-05 Study Group: Effect of low doses of corticosteroids in septic shock patients with or without early acute respiratory distress syndrome. Crit Care Med 34: 22-30, 2006.

15. SeamN,MeduriGU,WangH,NylenES,SunJ,SchultzMJ,Tropea M and Suffredini AF: Effects of methylprednisolone infusion on markers of inflammation, coagulation, and angiogenesis in early acute respiratory distress syndrome. Crit Care Med 40: 495-501, 2012.

16. Tongyoo S, Permpikul C, Mongkolpun W, Vattanavanit V, Udompanturak S, Kocak M and Meduri GU: Hydrocortisone treatment in early sepsis-associated acute respiratory distress syndrome: Results of a randomized controlled trial. Crit Care 20: 329, 2016.

17. ARDS Definition Task Force, Ranieri VM, Rubenfeld GD, Thompson BT, Ferguson ND, Caldwell E, Fan E, Camporota L and Slutsky AS: Acute respiratory distress syndrome: The Berlin definition. JAMA 307: 2526-2533, 2012.

18. Vincent JL, Akça S, De Mendonça A, Haji-Michael P, Sprung C, Moreno R, Antonelli M, Suter PM; SOFA Working Group. Sequntial organ failure assessment: The epidemiology of acute respiratory failure in critically ill patients(*). Chest 121: 1602-1609, 2002.
19. Meduri GU, Bridges L, Shih MC, Marik PE, Siemieniuk RAC and Kocak M: Prolonged glucocorticoid treatment is associated with improved ARDS outcomes: Analysis of individual patients' data from four randomized trials and trial-level meta-analysis of the updated literature. Intensive Care Med 42: 829-840, 2016.

20. Meduri GU, Muthiah MP, Carratu P, Eltorky M and Chrousos GP: Nuclear factor-kappaB- and glucocorticoid receptor alphamediated mechanisms in the regulation of systemic and pulmonary inflammation during sepsis and acute respiratory distress syndrome. Evidence for inflammation-induced target tissue resistance to glucocorticoids. Neuroimmunomodulation 12: 321-338, 2005.

21. Annane D, Pastores SM, Rochwerg B, Arlt W, Balk RA, Beishuizen A, Briegel J, Carcillo J, Christ-Crain M, Cooper MS, et al: Guidelines for the diagnosis and management of critical illness-related corticosteroid insufficiency (CIRCI) in critically Ill patients (Part I): Society of Critical Care Medicine (SCCM) and European Society of Intensive Care Medicine (ESICM) 2017. Crit Care Med 45: 2078-2088, 2017.

22. Snijders D, Daniels JM, de Graaff CS, van der Werf TS and Boersma WG: Efficacy of corticosteroids incommunity-acquired pneumonia: A randomized double-blinded clinical trial. Am J Respir Crit Care Med 181: 975-982, 2010.

23. Calfee CS, Delucchi K, Parsons PE, Thompson BT, Ware LB and Matthay MA; NHLBI ARDS Network: Subphenotypes in acute respiratory distress syndrome: Latent class analysis of data from two randomised controlled trials. Lancet Respir Med 2: 611-620, 2014. 